\title{
SATU BERITA, DUA PENDIRIAN: REPRESENTASI BERITA PERPINDAHAN KEDUTAAN AS KE YERUSALEM OLEH DUA KANTOR BERITA
}

\author{
One News, Two Stances: Two News Agencies' Representation of the US Embassy Move \\ to Jerusalem
}

\section{Ni Ketut Mirahayuni}

English Department, University of 17 Agustus 1945 Surabaya

ketutmirahayuni@untag-sby.ac.id

\begin{abstract}
Abstrak
Studi ini membandingkan dua representasi dari satu berita alam wacana media online. Fokus penelitian ini adalah pemberitaan tentang satu peristiwa dunia akhir-akhir ini: perpindahan kedutaan besar Amerika Serikat di negara Israel ke kota Yerusalem. Bahasa dalam media publik - seperti koran-membahas tiga unsur: representasi, identitas dan relasi (Fairclough, 1995). ? Studi ini menganalisis ketiga unsur tersebut dengan membandingkan pemberitaan satu peristiwa oleh dua sumber berita: Associated Press dan Aljazeera. Ketiga unsur yang direpresentasikan dalam tiga pertanyaan: (1) bagaimanakah dunia direpresentasikan?, (2) identitas apakah yang dibangun bagi mereka yang terlibat dalam program atau berita tersebut?, dan (3) hubungan-hubungan apakah yang dibangun di antara mereka yang terlibat di dalamnya? Studi ini menemukan persamaan dan perbedaan unsur kebahasaan yang amat mencolok di dalam dua teks tersebut. Persamaan tampaknya disebabkan adopsi teks sumber berita pertama oleh oleh sumber berita yang menyirkan belakangan. Namun perbedaan tampaknya menunjukkan representasi unsur-unsur secara berbeda di kedua teks.
\end{abstract}

Kata kunci: wacana media, representasi, identitas, relasi

\begin{abstract}
This papper is a comparation study of - two representations of one news in online media discourse. The focus of the study is the news on one recent world event: the US Embassy move to Jerusalem. Language in public affairs media-such as newsdiscusses three elements: representations, identities and relations (Fairlough, 1995). This study analyzes the three elements by comparing the same news event reported by two sources: Associated Press and Aljazeera news agencies in three sets of questions: (1) how is the world represented? (2) what identities are set up for those involved in the programme or story? and (3) what relationships are set up between those involved? The study found striking similarities and differences in the linguistic elements of the two texts. The similarity may be due to adoption of one text by one news agency from the other. Yet the differences may indicate differing representations of the elements in the two news.
\end{abstract}

Keywords: media discourse, representations, identities, relations 
How to Cite: Ni Ketut Mirahayuni. (2019). Satu Berita, Dua Pendirian: Representasi Berita Perpindahan Kedutaan As Ke Yerusalem Oleh Dua Kantor Berita. Ranah: Jurnal Kajian Bahasa, 8 (1), 111-122. doi: https://doi.org/10.26499/rnh.v8i1.925

\section{INTRODUCTION}

News has generally been thought of as a natural phenomenon by which professional journalists inform their societies about certain important issues. Moreover, newspapers have been an important vehicle of political communication in its early history in European and American culture, where the news itself, its associated practices, the organizations of its institutions, its formats, and genre, has its origin.

From the beginning, the news agencies provided not only news to the press, but also business intelligence to financial brokers and businessmen. They operate on the principle that 'almost anything that passes as news in print, broadcasting and electronic media is likely to have some financial implication for someone' and that the best stories 'move markets' (Boyd-Barrett, 1998:62, quoted in Machin and van Leuwen, 2007:8).

Academics, particularly sociologists, however, have shown that news is a set of institutional practices "that must be understood in terms of its social and historical development" (Machin and van Leuwen, 2007:7). Media discourse analysis has studied about the centrality of language in social life, that powerful ideas written or spoken by media professionals in authoritative ways about the world are made and renewed through each instance of language use (Matheson, 2007:2). Media discourse studies the media's connection to other parts of social and cultural life. According to Fairlough (1995), analysis of language of media texts can illuminate three essentials elements of media discourse, namely representations, identities and relations (Fairlough, 1995:5).

Critical discourse analysis has been adopted to analyze media discourse, among others, by Ali Kusno and Nur Bety (2017) to analyze language used in twitters by a political figure in Indonesia, Mohammedwesam Amer (2017) to analyze war reporting in the international press: the case of the Gaza war of 2008-2009, and a most recent study by Akbar and Abbas (2019) on representation of others in American Political Speeches.

This paper reports a study on news on one controversial recent world event: the US Embassy move to Jerusalem, as reported by two news agencies: Associated Press (www.foxnews.com) and Al Jazeera (www.aljazeera.com). Both agencies reported on 
June 1st and June 2nd, respectively, on the event of The US President Trump administration holding a ceremony in Jerusalem on Monday, May 14, 2018, to mark the opening of the U.S. Embassy in the city, relocating the U.S. Embassy from Tel Aviv to Jerusalem.

Prior to the event, in December 2017, the Trump administration already recognized Jerusalem as Israel's capital and begin the process of moving the embassy there (Tibon and Landau, 2018, Haaretz.com). Despite the limited number of offices to be initially moved from the embassy in Tel Aviv to the new location in Jerusalem, for the Israeli government, this preliminary move is considered as a major diplomatic achievement for its symbolic significance.

The Palestinian Authority and other Arab nations have strongly criticized the Trump administration's decision on Jerusalem, and the Arab League published a joint statement emphasizing that East Jerusalem should become the capital of Palestine. The event has even triggered more deadly confrontations on the already heated Israel's border with Gaza since Israel's capture of east Jerusalem in the 1967 Mideast war, annexing the eastern sector to its previously declared capital in the western part of the city. The opening of the U.S. Embassy in Jerusalem on May 14, 2018 has also triggered protests in the region. The 57-nations Organization of Islamic Cooperation, for example, "strongly rejects and condemns the USA's "deplorable action" to move the U.S. embassy in Israel from Tell Aviv to Jerusalem, and considers the action "an attack on the historical, legal, natural and national rights of the Palestinian people" and "an affront to international peace and security" (http://apnews.com/May 14, 2018). The Palestinians even consider the embassy move as a show of pro-Israel bias by the US President Donald Trump and a new blow to dreams of statehood ((http://apnews.com/May 13, 2018).

Yet, Daniel B. Shapiro, the U.S. Ambassador to Israel and Senior Director for the Middle East and North Africa at the National Security Council in the Obama Administration, wrote on the same date in CNN news, that moving US embassy to Jerusalem could help advance to end the conflict, that President Trump's announcement was actually "recognizing a reality... and correcting a long-held historical anachronism" (Shapiro, 2018, CNN). 
The study focuses on identifying Faiclough's three elements of representations, identities, and relations in the two media texts. Since the two texts show both striking similarities and differences, it is interesting to examine how Fairclough's three elements are represented in the media output. The study is expected to contribute a better understanding of media discourse in general, and of the use of linguistic elements in representation of aspects if news in media.

\section{THEORETICAL BASIS}

Studies of media, or also called communication studies, assumes that various forms of communication — such as radio, newspapers, television, and internet textingplay important roles in the society. Even the shared experiences and ways of living that make a culture are said to be partly constructed by the members of the society and partly by institutions such as newspapers or television or more recently, internet media. Media discourse analysis enables discourse analysists to assess and analyze the shared meaning. Media discourse analysis also examines how the social world is represented, what kind of interaction is established between the people and the world, and more importantly, how meaning is presented in different ways by different media. Matheson (2005) states that media establishes power "through their ways of using language" (2005:2). Matheson also modern media such as internet media involves not only text production but also "social conventions emerging around those texts and is about the social and cultural context in which those texts are consumed (Matheson, 2005:162).

According to Fairlough (1995), analysis of language of media texts can illuminate three essentials elements of media discourse, namely representations, identities, and relations, which are put into three sets of questions of media input:

1. How is the world (events, relationships, etc) represented?

2. What identities are set up for those involved in the programme or story (reporters, audiences, 'third parties' referred to or interviewed)?

3. What relationships are set up between those involved (e.g. reporter-audience, expert-audience, or politician-audience relationships)? (Fairlough, 1995:5).

Furthermore, analysis of the linguistic elements in the media discourse will able to show statements in the text, for example, the relationships between the reporter and the audience, the social identity for the reporter and the audience, that are established at 
the outset of the news reporting or programme. Media discourse analysists also identify the authoritativeness of the language and the reporters, how knowledgeable are the reporters represented as a figure of authority to inform the interested readers or audience. Media discourse also examines the choice of genre used in the reporting: a narrative genre, for instance, generally makes a more dramatic and entertaining account than a description of the events. Equally important in a media discourse analysis is the motives for the inclusion and exclusion of information, also "what to foreground and what to background" or even what is excluded altogether that helps to build a critical view of the event being reported (Fairclough, 1995:4-5).

\section{RESEARCH METHOD}

This study adopts descriptive qualitative approach to written text as the object of the study, with the purpose of finding explanation and interpretation of the language phenomena in the text. The data sources are two online news agencies: Associated Press and Aljazeera news agencies. The news was dated June 1st, 2018 (Associated Press, further referred to as AP) and June 2nd, 2018 (Al Jazeera, further referred to as AJ). Both texts present a recent world event on the USA embassy move to Jerusalem, with almost exactly the same title "After US Embassy move, Trump weighs Jerusalem consulate changes" except for the word "US" is missing in the Associates Press news. The two texts differ in length yet showing striking similarities and differences in the information amount being presented. Fairclough's (1995) three elements of news media analysis were identified and analyzed in the two texts, to answer the issues of representation, identities, and relations as represented in the two texts.

\section{DISCUSSION}

a. Similarities and differences in both news

Before analysing Fairclough's three elements of media discourse in the two texts, it is important to identify the similarities and differences occurring in the two texts. Analysis of the two texts shows linguistic differences in the two media texts. The similarities and differences in the news presentation begin from the titles of the texts. First, the two texts open with the same title with only one word missing in the Associated Press (AP) news, i.e. "US.": 
(1) AP title: "After Embassy move, Trump weighs Jerusalem consulate changes"

AJ title: "After US Embassy move, Trump weighs Jerusalem consulate changes"

The omission of the word "US" in the AP text may be due to the fact that AP headquarters is in the USA and the news specifically mentions the name of the country's president, it needs not specifically mentioning the identity of the country. The AJ agency headquarter is outside the USA and the news is presented under the USA \& Canada section.

Despite the similar title, both texts present different figures in their visual images. Interestingly, both visual images are not taken from the event being reported, as described in the source of the images: AP portrays the Israeli Prime Minister Benjamin Netanyahu and David Friedman, the new U.S. ambassador to Israel attending a ceremony celebrating the 50th anniversary of the liberation and unification of Jerusalem on May 21, 2017; while the AJ news portrays Friedman making a speech in an Ammar Award, a picture taken from Reuters.

(2) Visual images in the AP text (left) and in the AJ text (right)

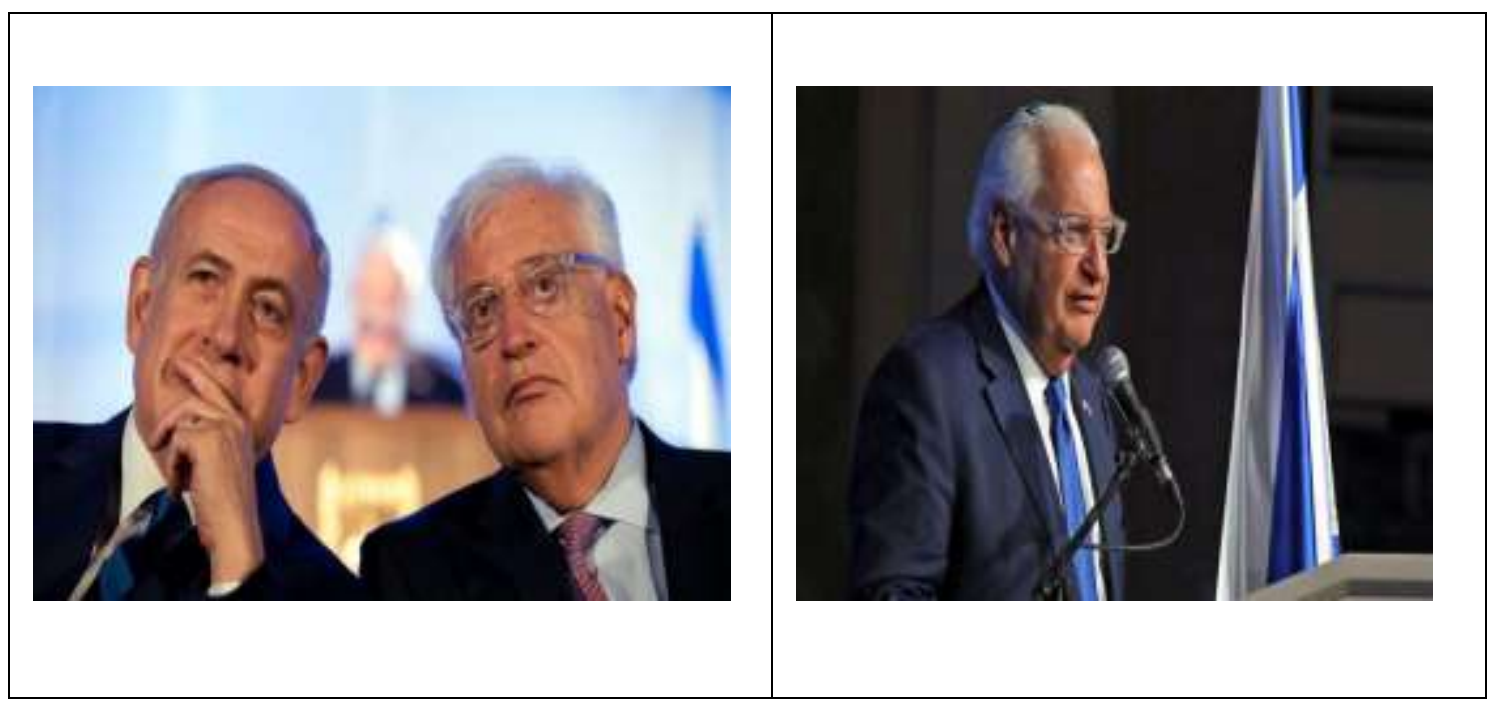

Second, The AJ news title is followed with a subtitle which is absence in the AP text:

(3) AJ Subtitle: "This move could suggest placing the Palestinian Authority under Israel's jurisdiction.” 
The addition of the subtitle in the AJ text indicates a causal relationship of the main title as the cause and the subtitle is the possible political result of the event to the Palestinian authority.

Third, The AP news text contains nine (9) paragraphs while the Al Jazeera (AJ) has fifteen (15). The sentences in the AJ news are corresponded with nine paragraphs exactly the same with those paragraphs in the AP news, with additions and omission of words and sentences and even paragraphs in between them. The AJ text presents five (5) other paragraphs that are not written in the AP text. Considering the broadcast dates, that the AJ news was issued a day later than the AP news, it is likely that the similarity may be due to adoption of the AJ news by the AP news agency.

b. Representation in the AP and AJ texts

The element of representation answer the question: How is the world represented? Both AP and AJ texts chose a descriptive genre to report the event. The first sentence in both texts is almost exactly the same, presented in a present continuous tense, indicating an ongoing process of the event:

(4) AP text: President Donald Trump is considering giving U.S. Ambassador to Israel David Friedman more authority over the U.S. outpost that handles Palestinian affairs, five U.S. officials said, a shift that could further dampen Palestinian hopes for an independent state.

AJ text: President Donald Trump is considering giving US Ambassador to Israel David Friedman more authority over Washington's diplomatic mission that handles Palestinian affairs, five US officials told The Associated Press news agency, a shift that could further dampen Palestinian hopes for an independent state.

The underlined words in the first sentence of the two texts above indicate the striking similarities yet significant differences in how each news agency views the event. The AP text states the U.S. embassy in Israel as "the U.S. outpost", which represents Israel as considered by the U.S. government as either a lonely part of the country or a military camp away from the main army to watch an enemy's movement. The AJ text, on the other hand, represents the embassy as "Washington's diplomatic mission", a more politically-neutral term that does not directly indicate "invasion" into 
the country. The reference to the AP news agency in the AJ text clearly shows that the latter was adopted from the earlier text.

Another different representation of the U.S. - Israel relations in the two texts is shown in the second sentence, which also strikingly similar:

(5) AP: Any move to downgrade the autonomy of the U.S. Consulate General in Jerusalem - responsible for relations with the Palestinians - could have potent symbolic resonance, suggesting American recognition of Israeli control over east Jerusalem and the West Bank.

AJ: Any move to downgrade the autonomy of the US Consulate General in Jerusalem-responsible for relations with the Palestinians - could have potent symbolic implications, suggesting American recognition of Israeli control over occupied East Jerusalem and the West Bank.

Two pairs of different wordings are shown in the second sentence of the AP and AJ texts. The formal yet obscure word "resonance" (AP) is replaced with more direct word "implications" (AJ), showing that the AP text represents more indirectly yet more powerfully than the AJ text in the suggestion that the U.S. government supports Israel's control over east Jerusalem and West Bank. The AJ text even represents more explicitly the unequal position between Israel, "the invader and controller" and East Jerusalem and the West Bank as the "occupied" region. Here, AJ text positions Israel as a foreign invader that came to control the region using military force. The U.S. embassy move is portrayed to support Israel's control over the region; the independence from whom has long been fought for by the Palestinians since Israel's occupation of East Jerusalem in the 1967 Mideast war.

c. Identities in the AP and AJ texts

Both the AP and AJ texts represent the identity of the news agencies as of authority: as the entities that have "the facts" and who know and have the right to tell the readers. The authoritativeness of the language is indicated not in presenting an authoritative figure or reporter, but in the choice of descriptive genre, which supports objectivity of the news. Despite several use of modal auxiliary (such as could, might) and its nominalized form indicating possibility (such as possibility, potentially) to indicate possible future socio-political impact of the decision, the use of simple present 
in most of the sentences indicates timeless, and therefore, generalised, statement of facts that becomes general knowledge. This is also supported with the use of statements by almost no mention of experts nor result of interview for the report.

Beside the identity of the news agencies as the source of information, the AJ text also include an anonymous American political figure, identified only with its position as a top Democratic legislator, as the expert of the information, whose presence in the AJ text is more likely to contradict the country's position as Israeli supporter.

(6) AJ: On Thursday, a top Democratic legislator even suggested Friedman should be recalled after he waded into domestic US politics on Israel's behalf, telling an Israeli newspaper that Democrats have failed to support Israel as much as Republicans.

The two texts represent the audience as the interested readers from all over the world, since the online news can be accessed world-wide. The AJ text provides more information (i.e. 5 more paragraphs in total) to provide more detailed information and emphasis on the potential impact of the U.S. policy on the region and worldwide, the peculiarity of the U.S. policy in contrast with the existing U.S. policy over Jerusalem prior to President Trump's administration, and a brief historical account on Israel occupation over the territory since 1967.

(7) AJ: Israel occupied Arab East Jerusalem, the West Bank and Gaza during the 1967 war along with the Syrian Golan Heights and the Egyptian Sinai Peninsula. Israel moved to annex occupied East Jerusalem in 1981 in violation of international law.

Such additional information seems to be foregrounded in the AJ text as a reminder for the readers of the history of the tension in the region. Even an illustration was given in the AJ text of the potential power rivalry between the existing U.S. Consulate and newly moved embassy in the same city of Jerusalem, separated only less than a mile away from each other, on who will have the ultimate authority for American citizens needs help. The common operational practice prior to the embassy move was that the U.S. consulate in Jerusalem operates differently from other U.S. Consulates: that it does not report directly to the U.S. embassy, but has a direct access to the State Department in Washington. 


\section{d. Relations in the AP and AJ texts}

In both $\mathrm{AP}$ and $\mathrm{AJ}$ texts, the relation between the reporter/agency and audiences is of an authoritative and knowledgeable information source which tells a receptive audience who is assumed to want to know and want to be told.

The mentioning of a U.S. Democratic political figure in the AJ text supports the relation type that the agency is trustworthy and objective. The legislator's negative comment on the U.S. new ambassador's political move supporting Israel, as indirectly reported in the text, clearly shows the agency's critical view of the event and its taking opposite side of the U.S. new policy over Israel and Palestine.

The last point in the analysis is the decision in foregrounding and backgrounding information. The AP news presents or foregrounds the coverage of the event mainly on the President Trump's decision and future policy which makes up the original nine AP paragraphs. The AJ news, however, in addition to the nine paragraphs taken from the AP news with some changes in the wordings in some parts of the similar paragraphs, adds other five paragraphs in between the original AP news, most of which provide more detailed account and illustration to the previous part of the news.

What is interesting about the two texts is that both foreground only the U.S. and Israel governments as the active actors in the event being reported. The U.S. government is represented as the entity of making new policy and also able to move to the Israeli territory. While the Israel government is represented as the welcoming receptor of the policy and able to move any party who will have the benefit from the event with stronger support for its control over the region.

Both texts do not provide information on the Palestinian reaction-or in other words, background the Palestinian government and people-, except for some comments on loss of hope for the Palestinians to have an independence. The AJ text represents the Palestinians and Palestinian government as the inflicted party of the event. Despite its mentioning that the U.S. policy has drawn "international condemnation and sparking a wave of heated protests around the world," it does not specifically foreground Palestinians as a third equal party directly impacted by the policy. This position builds an impression of an ambiguous position of the AJ text. While it does present the Palestinian authority as the inflicted and hurt by the event, 
incapable of defending itself of its rights, does not provide any room for the Palestinian reactions as of equal standing with the other two countries.

\section{CLOSING}

Media discourse analysis of the event on the U.S. embassy move to Jerusalem as reported by two news agencies has shown some interesting points. First, the adoption of one news source by the other does not necessarily follow that the latter is exactly the same as the source. The addition of information is given to support the news producer's purposes and representation. Analysis of the three elements of news output on the two similar but different news texts show that despite the striking similarity, both show differences in detailed representation of the world, identities of the participants in the news and the relationships between those involved in the news. The AP text shows a straightforward representation of the world, that the U.S. government considers Israel as its outpost, a strong statement on the authority of the U.S. Jerusalem embassy in relation to the Israel and particularly the Palestinian Authority. The AJ news is more neutral in reference to the embassy, yet its word choice on the possible implication of the embassy move against the Palestinian dream of independence shows its critical (if not negative) view of the U.S. government new policy. Both texts generally portray the reporters (in this case the news agencies) identity as the authoritative information sources with the audience identity as unknowledgeable, wanting to be told or informed. The descriptive genre being chosen in the information presented indicates that the two news agencies take the position as the authoritative source of information, allowing no possibility of negotiating nor challenging the validity of information being presented. Being authoritative in their position as sources of information, the relationship between the news producers and audience/readers is of objective information. Moreover, the news producers are active actors and the readers are passive one. Finally, both texts seem to generally take similar position towards the event, although the AJ text provides more detailed information to be foregrounded, which is absent in the AP text.

\section{BIBLIOGRAPHY}

Akbar, N. F. H., and Abbas, N. F., (2019). Negative other representation in American Political Speeches, International Journal of English Linguistics, Vol. 9, No.2, 2019. https://doi.org/105539/ijel.v9n2p113. 
Ali Kusno and Nur Bety. (2017). Analisa Wacana Kritis Cuitan Fahri Hamzah FH) Terkait Hak Angket Komisi Pemberantasan Korupsi KPK), Ranah, 6 (2), 137159. DOI: https://doi.org/10.26499/rnh.v6i2.462

Aljazeera. After US embassy move, Trump weighs Jerusalem consulate changes. June 2, 2018. https://www.aljazeera.com/news/2018/06/embassy-move-trump-weighsjerusalem-consulate-180601180158323.html (accessed: June 28th, 2018).

Amer, Mohammedwesam. (2017). Critical discourse analysis of war reporting in the international press: the case of the Gaza war of 2008-2009, Palgrave Communications volume 3, Article number: 13 (2017).

Fairclough, Norman. (1995). Media Discourse. London: Arnold.

Machin, David and van Leuwen, Theo. (2007). Global Media Discourse. London: Routledge.

Matheson, Donald. (2005). Media Discourse: Analyzing Media Text. England: Open University Press.

OIC condemns US embassy move to Jerusalem. May 14, 2018. Https://apnews. com/cb3a22180dd34947b59a73d05a07fe87 (accessed: July 6th, 2018).

Shapiro, Daniel B. (2018). Moving US embassy to Jerusalem could help end the conflict. CNN: https://edition.cnn.com/2018/05/11/opinions/us-embassy-movejerusalem-shapiro-opinion-intl/ index.html (accessed date: 20/5/2018).

The Associated Press. After embassy move, Trump weighs Jerusalem consulate changes. June, 1, 2018. https://www.usnews.com. (accessed: June 28th, 2018).

Tibon, Amir Tibon and Noa Landau, U.S. Embassy Move to Jerusalem: Everything You Need to Know. https://www.haaretz.com/israel-news/.premium-everything-youneed-to-know-about-the-u-s-embassy-in-jerusalem-1.6062554, May 14, 2018 (accessed: 10/07/2018). 